\title{
A Cross-sectional Study of Iranian EFL Learners' Request Strategies
}

\author{
Alireza Jalilifar \\ English Department, Shahid Chamran University of Ahvaz, Ahvaz, Iran \\ Email: Jalilifar20@yahoo.com \\ Mahmood Hashemian \\ English Department, Shahrekord University, Shahrekord, Iran \\ Email: m72h@hotmail.com \\ Madine Tabatabaee \\ Islamic Azad University - Ahvaz Science \& Research Branch, Ahvaz, Iran
}

\begin{abstract}
This study was a cross-sectional investigation into the request strategies used by Iranian learners of English as a Foreign Language (EFL) and Australian native speakers of English. The sample involved 96 B.A. and M.A. Iranian EFL learners and 10 native speakers of English. A Discourse Completion Test (DCT) was used to generate data related to the request strategies used by each group. The selection of request situations in the DCT was based on 2 social factors of relative power and social distance. Although the results revealed pragmatic development, particularly in the movement from direct to conventionally indirect strategies on the part of the EFL learners, the EFL learners with higher proficiency displayed overuse of indirect type of requesting, whereas the native group was characterized by the more balanced use of this strategy. The lower proficiency EFL learners, on the other hand, overused the most direct strategy type. In terms of the influence of the social variables, the findings of this research revealed that as far as social power is concerned, the EFL learners displayed closer performance to the native speakers. But considering social distance, it seems that the Iranian EFL learners had not acquired sufficient sociopragmatic knowledge to display proper social behavior.
\end{abstract}

Index Terms —requests, social distance, directness level, politeness

\section{INTRODUCTION}

Successful communication entails knowledge of grammar and text organization as well as pragmatic aspects of a second language (L2). Pragmatic competence is specifically defined by Koike (1989) as "the speaker's knowledge and use of rules of appropriateness and politeness which dictate the way the speaker will understand and formulate speech acts" (p. 279).

Austin (1962) defines speech acts as acts performed by utterances such as giving order, making promises, complaining, requesting, among others. When we utter a sentence or a phrase, we are performing an act to which we expect our listeners to react with verbal or nonverbal behavior (p. 65). According to Kasper (1984), what L2 learners must know for successful speech act performance has been presented in a "top down processing" manner: L2 learners first have to recognize the extra-linguistic, cultural constraints that operate in a native speaker's choice of a particular speech act appropriate to the context. They also have to know how to realize this speech act at the linguistic level and in accordance with the L2 sociocultural norms (p. 3).

The study of requests has attracted more attention in the study of speech acts. Considering Searle's (1969) classification of illocutionary acts (i.e., representatives, directives, expressives, commissives, and declarations), L2 researchers let requests fall under the second category, that of directives, which have been regarded as "an attempt to get hearer to do an act which speaker wants hearer to do, and which it is not obvious that hearer will do in the normal course of events or of hearer's own accord" (p. 66).

Based on Brown and Levinson's (1987) politeness theory, requests are Face Threatening Acts (FTAs) since a speaker is imposing her/his will on the hearer (p. 65). Brown and Levinson (1987) propose that when confronted with the need to perform a FTA, the individual must choose between performing the FTA in the most direct and efficient manner or attempting to mitigate the effect of the FTA on the hearer's face. The strategy an individual chooses to employ depends upon the weightiness or seriousness of FTA. Weightiness is an assessment of the social situation calculated by the speaker (p. 76).

The speaker considers three variables when assessing weightiness. First, the speaker appraises the degree of imposition associated with the FTA. Brown and Levinson (1987) define the degree of imposition as "a culturally and situationally defined ranking of impositions by the degree to which they are considered to interfere with an agent's wants of self-determination or of approval" (p. 77). Second, the speaker considers the relative power of the hearer, 
defined as "the degree to which the hearer can impose his own plans and his own self-evaluation (face) at the expense of the speaker's plans and self-evaluation" (p. 77). Third, the speaker evaluates the social distance between the speaker and the hearer which Brown and Levinson (1987) call the "symmetric social dimension of similarity/difference within which "the speaker and hearer" stand for the purpose "of an act and the kinds of goods exchanged between them" (p. 76).

Blum-Kulka, House, and Kasper (1989 cited in Francis, 1997) distinguished three degrees of directness in requests, depending on the extent to which the illocution is transparent from locution: Direct requests, conventionally indirect requests, and non-conventionally indirect requests. In direct requests, the illocutionary force of the utterance is indicated by grammatical, lexical, or semantic means (e.g., "Leave me alone."). Conventionally indirect statements express the illocution via fixed linguistic convention established in the speech community (e.g., "How about cleaning up?"). Nonconventionally indirect requests require the addressee to compute the illocution from the interaction of the locution with its context (e.g., "The game is boring.").

The request strategies in the following classification are ordered according to decreasing degree of directness. BlumKulka et al. (1989 cited in Francis, 1997, p. 28) summarize a combination of level of directness and strategy types in Cross Cultural Speech Act Realization Project (CCSARP) as follows:

a. Direct level

1. Mood derivable: Utterances in which the grammatical mood of the verb signals illocutionary force (e.g., "Leave me alone.").

2. Performatives: Utterances in which the illocutionary force is explicitly named (e.g., "I tell you to leave me alone.").

3. Hedged performatives: Utterances in which naming of the illocutionary force is modified by hedging expressions (e.g., "I would like to ask you to leave me alone.").

4. Obligation statements: Utterances which state the obligation of the hearer to carry out the act (e.g., "Sir, you'll have to move your car.").

5. Want statements: Utterances which state the speaker's desire that the hearer carries out the act (e.g., "I want you to move your car.").

b. Conventionally indirect level

6. Suggestory formulae: Utterances which contain a suggestion to do something (e.g., "How about cleaning up?").

7. Query-preparatory: Utterances containing reference to preparatory conditions (e.g., ability, willingness) as conventionalized in any specific language (e.g., "Would you mind moving your car?").

c. Non-conventionally indirect level

8. Strong hints: Utterances containing partial reference to object or element needed for the implementation of the act (e.g., "The game is boring.").

9. Mild hints: Utterances that make no reference to the request proper (or any of its elements) but are interpretable as requests by context (e.g., "We've been playing this game for over an hour now.").

During the last decade, requests have been one of the most commonly researched speech acts in both cross-cultural and interlanguage studies. Cross-cultural pragmatic researchers have analyzed speech acts across a range of languages to investigate whether there are universal pragmatic principles in speech act realizations, and if so, what the characteristics of these universals are (Chen, 2007; Eslamirasekh, 1993; Rinnert \& Kobayashi, 1999).

On the other hand, focusing on second language acquisition (SLA), many interlanguage researchers have studied differences and similarities that exist in carrying out communication actions among L2 learners and native speakers of an L2. Some SLA researchers explored the speech act of request in English (Francis, 1997; Kaneko, 2004; Kim, 1995; Parent, 2002). Other studies focused on request realization in Spanish (Ruzickova, 2007), and in Japanese (Kahraman \& Akkus, 2007; Kubota, 1996).

Most of the studies mentioned above deal with interlanguage pragmatic performance (also see Garcia, 2004) while, as Rose (2000) notes, "unlike performance research, studying pragmatic development requires either longitudinal research with a given group of participants over an extended period of time, or cross-sectional studies with participants at various stages of development" (p. 29).

Among the above studies, only Francis (1997) and Parent (2002) attempted to examine developmental pragmatics by comparing data from L2 learners at various levels of proficiency while other studies were, in fact, "single-moment" research- they did not compare L2 learners at different levels of proficiency but, instead, just compared nonnative and native speakers (Rose, 2000, p. 29). These studies are capable of providing information regarding interlanguage pragmatics (ILP) performance, but they say nothing about development. They provide no information concerning the extent to which nonnative speakers will approximate native norms of speech act.

In addition, there is little information available about how lower proficiency L2 learners understand different kinds of requests and, in fact, they have been ignored in such studies. It is highly likely that lower proficiency L2 learners have problems selecting appropriate request strategies in different situations (Ellis, 1994). Therefore, concerning the importance of this area in L2 learning and teaching, this study sets out a cross-sectional research that surveys the development of request strategies by Iranian EFL learners at various levels of language proficiency. So, the current study attempts to (1) uncover the relationship between L2 learners' level of language proficiency and complexity of 
request strategies, and (2) find the possible difference in the type and frequency of the request strategies made by Iranian EFL students and native speakers of English based on social constraints of power and distance.

\section{MEthodOLOGY}

\section{A. Participants}

The nonnative participants in this study were 96 B.A. seniors and M.A. students majoring in Teaching English as a Foreign Language (TEFL) and English Language Translation. The B.A. students had studied English for at least three years at Shahid Chamran University of Ahvaz and had passed several courses in grammar, reading, conversation, and writing up to the advanced level. So, it was assumed that they had enough proficiency in oral and written L2 production.

The M.A. students were studying at Center for Science and Research in Ahvaz at the time of study. They had already passed National M.A. Entrance Examination that focuses partly on subject specific courses and partly on English language proficiency. On the other hand, their M.A. courses required writing classroom papers, so they were supposed to enjoy a good command of the English language.

All the participants also sat for Nelson Language Proficiency Test (Fowler \& Coe, 1976). They were, then, divided into three groups representing low, mid, and high L2 learners. Ten native Australian speakers of English also participated in the study via email. They were the employees of a company, and none of them had received any university degree.

\section{B. Instrument}

The instruments used in this study were Nelson English Language Proficiency Test (Fowler \& Coe, 1976) and a Discourse Completion Test (DCT). The Nelson Test included 50 multiple-choice items covering grammar, vocabulary, and reading comprehension. According to Fowler and Coe (1976), all the items in this test have been carefully pretested and cover the most accurate means of measuring the general standard of English which forms the basis for specific skills, such as composition writing and comprehension (p. 7). Each item was assigned one point, and so the overall score was 50 .

In a DCT, the speakers are given a scene or background information, such as what the previous speaker had said and the speakers' relationship with one another. Upon conducting the DCT in this study, 24 situations were given to the participants in written form based on relative power and social distance.

The power variable is treated as a ternary value, that is the hearer is either of lower status (+power), interlocutors are of equal status (=power), or the hearer is of higher status (-power). The distance variable is treated as a binary value, that is interlocutors either know each other (-distance) or they do not know each other (+distance). The combination of these two social variables results in 6 possible combinations, each realized in 4 situations which, thus, resulted in 24 situations (see Appendix for a sample questionnaire). The following table demonstrates the 6 variable combinations and the 24 situations:

TABLE 1.

POWER AND SOCIAL Distance Combinations

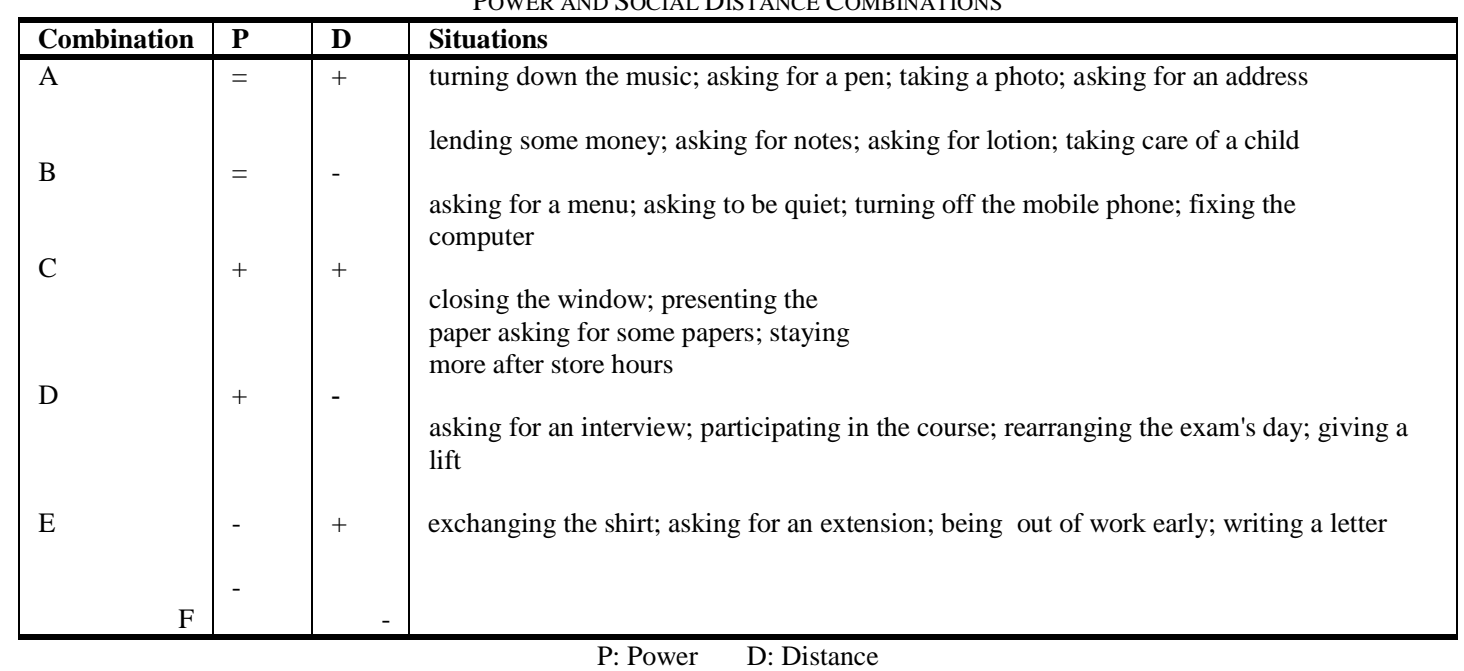

\section{Procedure}

First, the advanced test of Nelson (Fowler \& Coe, 1976) was administrated to 96 of the participants, and the mean (M) and the standard deviation (SD) of their scores were calculated. The M score was 30.38, and the SD was 5.31. The participants whose scores fell between 0.5 SD (2.65) above or below M were considered as mid level; those whose scores fell above or below this area were regarded as high and low L2 learners, respectively. So, the participants were 
divided into three groups: 25 participants, representing the lower group; 43, the mid level; and 28, the high level students.

Next, their pragmatic competence was challenged on the effective use of request strategies by means of DCT in which they had to write down what they would say in the given contexts. Data from the native speakers of English was also gathered via e-mail. The DCT was sent to 25 Australian native speakers with whom the researchers were in contact, but only 10 were completed and returned.

To analyze the data gathered from the EFL learners and the native speakers of English, the particular coding scheme, the CCSARP was used. This coding scheme is a universally valid scale of directness, which had previously been empirically tested and successfully used by many researchers (Lwanga-Lumu, 2002; Wouk, 2006). The CCSARP schematized requesting strategies in 3 categories: Directness level, internal modification, and external modification. The focus of this study was on directness level of requesting strategies which was classified as a nine-point scale: Mood derivable, Performatives, Hedged performatives, Obligation statement, Want statement, Suggestory formulae, Query preparatory, Strong hints, and Mild hints.

The analysis of the data took into consideration only the head acts which were isolated and classified based on the 9 levels of directness. The data were, then, submitted to the SPSS (version 14.0) for frequency analysis and chi square test. The frequency analysis was conducted to identify the proportion and percentage of request strategies used by the nonnative and the native speakers in 6 combinations. Then, the data was classified into 3 main categories: Direct, conventionally indirect, and hints. And again, the frequency of the use of the above 3 main categories of request strategies was calculated. Chi square test was performed in order to establish whether the differences in the frequency of strategies made by participants were statistically significant.

\section{RESULTS AND DISCUSSION}

\section{A. Question One}

In order to identify the type and frequency of request strategies made by EFL learners, the data was analyzed, and the frequency of occurrence and percentage of each category of strategies were calculated and tabulated in Table 2 . In order to find the relationship between L2 proficiency levels of Iranian learners and the type and frequency of request strategies, the Chi-square test was applied. The result of this test is presented in Table 3.

The findings of this study provide some evidence of correlation between EFL learners' level of language proficiency and type of requesting. As illustrated in Table 2, conventional indirectness was the most frequent strategy by the three groups of EFL learners which was conveyed by only one indirect substrategy: Query preparatory. Almost exclusively, this strategy constituted more than half of all requests produced by the EFL learners.

Following Brown and Levinson (1987), higher levels of indirectness may result in higher levels of politeness. So, direct requests appear to be inherently impolite and face-threatening because they intrude in the addressee's territory (p. 17). More specifically, Blum-Kulka (1985 cited in Brown \& Levinson, 1987, p. 19) suggests that in request at any rate, politeness and indirectness are linked for conventional indirectness requests but not necessarily in cases of nonconventional indirectness.

Hassall (2003) mentions formal simplicity as another factor that probably contributes to L2 learners' use of conventionally indirect strategy type. This type of Modal question is structurally simple, consisting minimally of Modal verb+ Agent+ Verb (e.g., May I borrow). So, L2 learners are unlikely to be discouraged by considerations of formal complexity in selecting this strategy (p. 1918).

Consequently, Trosborg (1995) remarks on the ability of learner subjects from all proficiency groupings in her study to use the conventionally indirect strategies of politeness. Interestingly, the present finding confirms and extends that of Trosborg (1995). It shows that even the low L2 learners are able consistently to select a polite, conventionally indirect strategy in the L2, when the L2 pragmalinguistic strategy form is formally simple and the same strategy exists in their first language (L1).

In general, the results of this study indicate that with increasing proficiency level, L2 learners use of direct requesting-mainly Imperative-decreases and, at the same time, conventionally and non-conventionally indirect types of requesting increase, while the lower level L2 learners overuse direct requests and the high and mid groups overuse conventional indirectness.

The fact that Iranian lower proficiency L2 learners use direct type of requesting more than other L2 learners can be explained by the notion of transferability. Interlanguage and cross cultural pragmatic studies have provided ample evidence that L2 learners' pragmatic knowledge significantly influences their comprehension and production of pragmatic performance in the L2 (Kasper, 1992; Takahashi, 1996). A pragmalinguistic transfer is the influence of the learners' knowledge about the illocutionary force or politeness value assigned to particular linguistic form-functions in their L1 which, when mapped by L2 learners into the perception and production of a similar situation in an L2, sounds different to native speakers.

Since Persian-speaking students use significantly more direct strategies compared to English speakers (Eslamirasekh, 1993), the low proficient L2 learners negatively transfer their pragmalinguistic forms of directness levels in request realization. That is, where more indirectness is demanded in English, they prefer direct strategies. In other words, to achieve requestive goals, the low proficient L2 learners in the present study may resort to a familiar and easy form of 
requesting, which has been experienced in their L1. The higher proficient L2 learners, on the other hand, are found not to transfer the Persian request strategies and, thus, pose more indirect strategy types in their interlanguage request. So, L2 proficiency is positively related to pragmatic transfer.

Concerning the correlation between complexity of request strategies and level of language proficiency in EFL learners, the findings of the present study, following other studies in this field (Francis, 1997; Harlow, 1990; Parent, 2002), support request development of L2 learners from being direct to indirect and from being simple to complex. On the one hand, there is a positive correlation between the use of indirect strategy types and the English proficiency level. In other words, the higher proficiency group used more indirect strategy types (both conventionally and nonconventionally indirect strategy) than L2 learners with lower language proficiency.

On the other hand, complexity of request strategies is explained in terms of direct strategies with forms that convey requestive force by purely syntactic means, such as grammatical mood or an explicit performative verb. Due to a strong concern with clarity, direct strategies may be considered as the most efficiently and easily expressed utterances. But in conventionally indirect strategies, the relationship between the surface form of an utterance and its underlying purpose is not straightforward. Again, requestive hints, as mentioned by Weizman (1993), tend to lack clarity and the speaker exploits their opacity while getting the hearer to carry out the implicitly requested act (p. 71).

Other substantial differences include lower L2 learners' reliance on Imperative strategy and other groups' tendencies for varieties of direct substrategies other than Imperative strategy. It is likely that higher proficiency L2 learners may have attempted to use as many strategies as possible in order to compensate for their lack of L2 proficiency, resulting in the use of different types of requesting. In contrast, the lower proficiency L2 learners are probably not sufficiently competent to use as wide a variety of strategies as the proficient L2 learners and, thus, they mainly rely on Imperative strategy. In other words, linguistic ability correlates with strategy use. The greater use of Imperative as the most direct type of requesting by the low L2 learners, as Harlow (1990) suggests, is also probably due to the linguistic deficiency or perhaps lack of attention to the rules of politeness (p. 335). They do not possess enough linguistic ability to employ other types of direct request, such as Want statement as frequent as the higher groups. So, it may be claimed that L2 learners with lower language proficiency show a particularly strong preference for Imperative because this subcategory, especially in elided form, does not demand high linguistic proficiency; it is formally very simple (e.g., Give me the pen.).

TABLE 2.

FREQUENCY AND PERCENTAGE OF REQUEST STRATEGIES BY EFL LEARNERS

\begin{tabular}{|l|l|l|l|}
\hline Strategy & $\begin{array}{l}\text { Low } \\
\text { F }(\%)\end{array}$ & $\begin{array}{l}\text { Mid } \\
\text { F (\%) }\end{array}$ & $\begin{array}{l}\text { High } \\
\text { F (\%) }\end{array}$ \\
\hline Mood Derivable & $181(34.60)$ & $119(18.91)$ & $238(24.48)$ \\
\hline Performative & $0(0)$ & $7(1.11)$ & $7(0.72)$ \\
\hline Hedge & $18(3.44)$ & $34(5.40)$ & $44(4.52)$ \\
\hline Obligation & $2(0.38)$ & $1(0.15)$ & $12(1.23)$ \\
\hline Want Statement & $16(3.05)$ & $41(6.51)$ & $47(4.83)$ \\
\hline Suggestory & $1(0.19)$ & $0(0)$ & $0(0)$ \\
\hline Preparatory & $290(55.44)$ & $396(62.95)$ & $570(58.64)$ \\
\hline Strong hints & $15(2.86)$ & $28(4.45)$ & $52(5.34)$ \\
\hline Mild hints & $0(0)$ & $3(0.47)$ & $2(0.20)$ \\
\hline Total & 523 & 629 & 972 \\
\hline
\end{tabular}

TABLE 3.

CHI- SQUARE VALUE OF EFL LEARNERS' REQUEST STRATEGIES

\begin{tabular}{|l|l|l|l|}
\hline & Value & Sig. & df \\
\hline Chi-Square & 90.98 & 18 & 0.000 \\
\hline \multicolumn{2}{|c|}{$p<0.05$} & Critical Value $=28.8$
\end{tabular}

\section{B. Question Two}

Addressing the first part of the second research question, concerning request strategies made by Iranian EFL learners and Australian native speakers of English, the study presents the results of comparison between the native and the nonnative speakers. As indicated in Table 4, all groups displayed a markedly high frequency of conventionally indirect strategy conveyed by Preparatory substrategy. However, while the mid and high groups displayed an inclination toward the use of this particular strategy, the native group was characterized by a more balanced use of conventional indirectness. The low group, on the hand, extraordinarily used the most direct type of requesting, that is, Imperative.

The considerable use of conventionally indirect strategy by both the native and the nonnative speakers may be due to the influence of Western language usage with regard to speech act theory. Previous studies (Leech, 1983; Searle, 1969) have mentioned that indirect speech acts correlate with politeness in Western cultures because Western language usage is fundamentally associated with negative politeness (Brown \& Levinson, 1987).

The results of this study are consistent with the findings of previous studies, such as Byon (2004). First, they support the view that advanced L2 learners appear to develop greater sensitivity to the use of politeness strategies in requesting 
than is seen in native speakers. Second, the study supports Ellis's (1994) idea that even advanced L2 learners do not acquire fully native-like ways of requesting.

On the one hand, the higher proficient EFL learners in the present study employed more conventionally indirect strategies than the native speakers. On the other hand, Brown and Levinson (1987) and Leech (1983) make a strong connection between the indirectness and politeness, arguing that a higher degree of indirectness shows more politeness. More specifically, Blum-Kulka (1987 cited in Marti, 2006, p. 1839) reports the most polite strategies in English are perceived to be conventionally indirect ones. Therefore, by greater use of conventionally indirect strategies, the higher proficient L2 learners show greater sensitivity to the use of politeness strategies in requesting. Overusing conventionally indirect types of requesting by high level L2 learners may have to do with the fact that high levels of grammatical competence do not ensure high levels of pragmatic competence. However, the majority of studies which have looked at the relationship between grammatical and pragmatic competence show that proficient L2 learners seem to be better at using speech act strategies (Trosborg, 1995) and comprehending illocutionary force (Koike, 1989). In short, the literature presents two generally accepted claims about the relationship between grammatical and pragmatic competence: (1) grammar is not a sufficient condition for pragmatic competence; however, (2) grammar is a necessary condition for pragmatic competence (Koike, 1989; Levinson, 1983).

The first claim is based on the observation that an L2 learner already knows linguistic structures, but has not yet learnt to use them as some pragmatic strategies (Bardovi-Harlig \& Dörnyei, 1998). The second claim is based on the observation that an L2 learner knows the appropriate pragmatic strategy for a given context, but does not know how to realize it due to limited linguistic knowledge (Takahashi \& Beebe, 1993). This fact might be a possible reason behind the overusing of direct strategies by the low EFL learners in the present study.

As a matter of fact, the higher frequency of direct strategies among the lower proficiency L2 learners is probably a developmental stage where simpler and also more direct expressions are being used. The low proficiency L2 learners use direct type of requesting because of lack of lexical and syntactic knowledge to produce an indirect request strategy which requires more complex structures.

This tendency among the low group results from L1 transfer since direct request is the common form of request speech act in the Persian language (Eslamirasekh, 1993). So, it is reasonable to claim that this strategy is used by the low L2 learners automatically in English; since the two other request types used by native speakers of English are more grammatically complex, they may not be automatized in the L2 learners' interlanguage. The low L2 learners, then, seek to mitigate or avoid face-threatening behavior in ways they know best. In this regard, Olshtain and Cohen (1991) mention that "second language learners' attempts to translate conventional routines specific to first language verbatim into the second language often result in miscommunication even if the results of their attempts are grammatically correct" (p. 155). A negative correlation is found between the likelihood of transfer and the level of proficiency. Advanced L2 learners excel lower L2 learners at identifying contexts where L1 speech act strategies could or could not be used.

It is important to note that in the present study non-conventionally indirect strategies are the least made request types in all groups. The underuse of this strategy by native speakers might be due to the fact that native speakers of English conceive of this type of requesting as being less polite than conventionally indirect strategy (Blum-Kulka 1987 cited in Brown \& Levinson, 1987). In line with this view, Weizman (1993) affirms that non-conventionally indirect request requires the hearer to deduce the speaker's intention, which can be a burden to the hearer. The highly inferential nature of this strategy may be the major cause for their being regarded as less polite than conventionally indirect strategies (p. 125).

L2 learners, specially the low proficiency group, are probably not sufficiently competent to use this type of requesting that is considered the most complex and indirect strategy. It is also important to mention that nonconventionally indirect requests require the addressee to compute the illocution from the interaction of the locution with its context (Ruzickova, 2007, p. 1177). Accordingly, it is believed by many SLA researchers that L2 learners acquire the use of utterances with opaque illocutionary meanings later in their pragmatic acquisition. High indirect pragmatic strategies like hinting require high processing cost and, therefore, such strategies may be more difficult to acquire (Bouton, 1994; Kasper \& Schmidt, 1996).

The findings of this study, on the other hand, contradict that of Weizman (1993) and Trosborg (1995) in which L2 learners used non-conventionally indirect strategies more than native speakers. Weizman (1993) suggests that Hints have a highly "deniability potential." Accordingly, the overuse of Hints by L2 learners may result from their exploitation of the inferential nature of Hints in order to save their own face (p. 95).

Trosborg (1995) suggests that L2 learners get no further than making a preliminary to a request because they are doubtful about how to phrase the actual request. The addressee, however, interprets the preliminary move as Hints, eliminating the need for the L2 learner to make real request at all. 
TABLE 4.

FREQUENCY AND PERCENTAGE OF REQUEST STRATEGIES BY ALL GROUPS

\begin{tabular}{|l|l|l|l|l|}
\hline Strategy & $\begin{array}{l}\text { Low } \\
\text { F (\%) }\end{array}$ & $\begin{array}{l}\text { Mid } \\
\text { F (\%) }\end{array}$ & $\begin{array}{l}\text { High } \\
\text { F (\%) }\end{array}$ & $\begin{array}{l}\text { Negative } \\
\text { F (\%) }\end{array}$ \\
\hline Mood Derivable & $181(34.60)$ & $238(24.48)$ & $119(18.91)$ & $48(21.23)$ \\
\hline Performative & $0(0)$ & $7(0.72)$ & $7(1.11)$ & $0(0)$ \\
\hline Hedge & $18(3.44)$ & $44(4.52)$ & $34(5.40)$ & $5(2.21)$ \\
\hline Obligation & $2(0.38)$ & $12(1.23)$ & $1(0.15)$ & $7(3.09)$ \\
\hline Want Statement & $16(3.05)$ & $47(4.83)$ & $41(6.51)$ & $19(8.40)$ \\
\hline Suggestory & $1(0.19)$ & $0(0)$ & $0(0)$ & $0(0)$ \\
\hline Preparatory & $290(55.44)$ & $570(58.64)$ & $396(62.95)$ & $126(55.75)$ \\
\hline Strong hints & $15(2.86)$ & $52(5.34)$ & $28(4.45)$ & $21(9.29)$ \\
\hline Mild hints & $0(0)$ & $2(0.20)$ & $3(0.47)$ & $0(0)$ \\
\hline Total & 523 & 972 & 629 & 226 \\
\hline
\end{tabular}

TABLE 5.

CHI- SQUARE VALUE OF REQUESTS BY ALL GROUPS

\begin{tabular}{|c|c|c|c|}
\hline & Value & df & Sig. \\
\hline Chi-Square & 125.40 & 27 & 0.000 \\
\hline
\end{tabular}

As for the second part of the question-difference in the type and frequency of the request strategies made by Iranian EFL students and the native speakers of English based on social constrains of power and distance-the analysis of the distribution of the request strategy types in six combinations of situations is discussed here in the following parts:

\section{Combination A}

The analysis of the request strategies used by the native and the nonnative speakers reveals that in combination A (= $\mathrm{P}+\mathrm{D})$, the use of conventionally indirect strategies plays a significant role as the most favored for both the native speakers and the EFL learners (see Table 6 for the frequency of strategy types and Table 7 showing the difference). According to Blum-Kulka et al. (1989 cited in Chen, 2007, p. 46), the level of directness of a request has strong correlation with the expectation of right and obligations between hearers and speakers. The greater the right of the speaker to ask and the greater the obligation of the hearer to comply with the request, the less motivation for the use of indirectness. Relative dominance also affects the level of indirectness. That is, the greater the speaker's dominance (power) to the addressee, the lower the use of indirectness is expected. Additionally, as argued by Rue, Zhang, and Shin (2007), when the interlocutors do not know each other, there is a strong trend of employing conventionally indirect strategy type of requesting.

The EFL learners displayed developmental patterns in using indirectness in these situations. In other words, a decline in direct request is observed with increasing proficiency. The main reason might be their sufficient pragmatic competence in relation to the effect of social power on choosing the contextually proper type of requesting. However, the higher proficiency EFL learners in this study are more indirect than the native speakers. Similarly, in the previous ILP studies (Byon, 2004), the advanced L2 learners appear to develop a greater sensitivity to the use of politeness strategies in requesting than native speakers. That is, EFL learners sometimes experience communication breakdown due to overgeneralizing stereotypes of an 12 culture. In this case, they tend to overuse conventionally indirect strategy which is considered as the most polite type of requesting.

TABLE 6.

FREQUENCY AND PERCENTAGE OF STRATEGIES BY ALL GROUPS IN COMBINATION A

\begin{tabular}{|l|l|l|l|l|}
\hline Strategy & $\begin{array}{l}\text { Low } \\
\text { F (\%) }\end{array}$ & $\begin{array}{l}\text { Mid } \\
\text { F (\%) }\end{array}$ & $\begin{array}{l}\text { High } \\
\text { F (\%) }\end{array}$ & $\begin{array}{l}\text { Negative } \\
\text { F (\%) }\end{array}$ \\
\hline Mood Derivable & $23(24.21)$ & $26(15.66)$ & $6(5.45)$ & $7(17.50)$ \\
\hline Performative & $0(0)$ & $2(1.20)$ & $0(0)$ & $0(0)$ \\
\hline Hedge & $6(6.31)$ & $8(4.81)$ & $3(2.72)$ & $0(0)$ \\
\hline Obligation & $0(0)$ & $0(0)$ & $0(0)$ & $0(0)$ \\
\hline Want Statement & $0(0)$ & $0(0)$ & $2(1.81)$ & $0(0)$ \\
\hline Suggestory & $0(0)$ & $0(0)$ & $0(0)$ & $0(0)$ \\
\hline Preparatory & $63(66.31)$ & $119(71.68)$ & $92(83.63)$ & $31(77.50)$ \\
\hline Strong hints & $3(3.15)$ & $11(6.62)$ & $7(6.36)$ & $2(5.00)$ \\
\hline Mild hints & $0(0)$ & $0(0)$ & $0(0)$ & $0(0)$ \\
\hline Total & 95 & 166 & 110 & 40 \\
\hline
\end{tabular}

TABLE 7.

CHI- SQUARE VALUE OF COMBINATION A

\begin{tabular}{|l|l|l|l|}
\hline & Value & df & Sig. \\
\hline Chi-Square & 31.16 & 18 & 0.02 \\
\hline \multicolumn{4}{|c|}{ Critical Value $=28.86$}
\end{tabular}




\section{Combination $B$}

Considering the correlation between the level of indirectness of requesting and expectations of rights and obligations between the interlocutors, the native speakers showed less motivation for the use of indirectness. Since there is equal social status between the speaker and the hearer (e.g., friends), the requester is not endowed with a contracted right to make his/her request, just as the requestee who is by no means obligated to comply with it. Therefore, the request may be performed without abundance of politeness. As compared with addressing the familiar equal person, the native speakers seemed to be more direct by employing direct substrategies as the second preferred type of requesting (see Table 8 for the frequency of strategy types and Table 9 showing the difference).

On the contrary, the EFL learners mainly relied on the conventional indirectness which implies the fact that they do not acquire the sociopragmatic knowledge necessary to perform appropriate request type which is contextually proper under the varying social distance. In other words, by keeping the same trend of indirectness in two combinations, the EFL learners are not sensitive enough to the effect of social distance to utilize more variation in the types of request strategy.

It is likely that Iranian EFL learners are not taught how to perform appropriate speech act under varying situational features. So, they may produce grammatically correct utterances, but inauthentic performance in terms of real language use.

TABLE 8.

FReQuency AND Percentage Of Strategies By All Groups In COMbination B

\begin{tabular}{|l|l|l|l|l|}
\hline Strategy & $\begin{array}{l}\text { Low } \\
\text { F (\%) }\end{array}$ & $\begin{array}{l}\text { Mid } \\
\text { F (\%) }\end{array}$ & $\begin{array}{l}\text { High } \\
\text { F (\%) }\end{array}$ & $\begin{array}{l}\text { Negative } \\
\text { F (\%) }\end{array}$ \\
\hline Mood Derivable & $18(19.56)$ & $28(16.76)$ & $11(10.28)$ & $9(23.07)$ \\
\hline Performative & $0(0)$ & $0(0)$ & $0(0)$ & $0(0)$ \\
\hline Hedge & $2(2.17)$ & $6(3.59)$ & $6(5.60)$ & $0(0)$ \\
\hline Obligation & $0(0)$ & $0(0)$ & $0(0)$ & $0(0)$ \\
\hline Want Statement & $2(2.17)$ & $4(2.39)$ & $4(3.73)$ & $4(10.25)$ \\
\hline Suggestory & $0(0)$ & $0(0)$ & $0(0)$ & $0(0)$ \\
\hline Preparatory & $67(72.82)$ & $118(70.65)$ & $79(73.83)$ & $19(48.71)$ \\
\hline Strong hints & $3(3.26)$ & $11(6.58)$ & $7(6.54)$ & $7(17.94)$ \\
\hline Mild hints & $0(0)$ & $0(0)$ & $0(0)$ & $0(0)$ \\
\hline Total & 92 & 167 & 107 & 39 \\
\hline
\end{tabular}

TABLE 9.

CHI- SQUARE VALUE OF COMBINATION B

\begin{tabular}{|c|c|c|c|}
\hline & Value & df & Sig. \\
\hline Chi-Square & 29.60 & 15 & 0.01 \\
\hline
\end{tabular}

\section{E. Combination $C$}

In addressing unfamiliar people in the lower position, nonnative speakers are more direct than native speakers. While the native speakers used both direct and indirect strategies as the preferred type of requesting, the EFL learners chose direct request as the preferred strategy. Among them, the low level L2 learners show strong tendency towards the use of the most direct type of requesting-Imperative.

In general, both the native speakers and the EFL learners were more direct in comparison with the previous situations in which they were requesting someone with equal power. In situations of this type, the requester (e.g., customer, teacher) has authority over the requestee (e.g., waiter, student). The greater the right of the speaker to ask and the greater the obligation of the hearer to comply with the request, the greater the likelihood of licensing direct request. Regarding the social distance between the interlocutors, the speaker and the hearer do not know each other, and so there is a strong trend of employing conventionally indirect strategy type.

Obviously, the native speakers showed sensitivity to both social power and social distance by utilizing more variation in the types of requesting. Therefore, they used both direct and indirect strategies. The overuse of direct request might display L2 learners' sensitivity to social power, but their unawareness of the effect of social distance.

The overuse of Imperative by the low EFL learners might suggest their insufficient pragmatic competence which makes them unable to use the necessary pragmalinguistic means to express an appropriate request. Moreover, the fact that the higher EFL learners displayed closer performance to the native speakers in terms of indirectness demonstrates a developmental pattern in their interlanguage request. This finding supports grammatical competence as a necessary condition for pragmatic competence (Bardovi-Harlig, 1999). 
TABLE 10.

FREQUENCY AND PERCENTAGE OF STRATEGIES BY ALL GROUPS IN COMBINATION C

\begin{tabular}{|l|l|l|l|l|}
\hline Strategy & $\begin{array}{l}\text { Low } \\
\text { F (\%) }\end{array}$ & $\begin{array}{l}\text { Mid } \\
\text { F (\%) }\end{array}$ & $\begin{array}{l}\text { High } \\
\text { F (\%) }\end{array}$ & $\begin{array}{l}\text { Negative } \\
\text { F (\%) }\end{array}$ \\
\hline Mood Derivable & $68(74.72)$ & $82(49.69)$ & $56(51.85)$ & $14(36.84)$ \\
\hline Performative & $0(0)$ & $0(0)$ & $0(0)$ & $0(0)$ \\
\hline Hedge & $0(0)$ & $3(1.81)$ & $3(2.77)$ & $0(0)$ \\
\hline Obligation & $1(1.09)$ & $5(3.03)$ & $1(0.92)$ & $3(7.89)$ \\
\hline Want Statement & $3(3.29)$ & $3(1.81)$ & $5(4.62)$ & $1(2.63)$ \\
\hline Suggestory & $0(0)$ & $0(0)$ & $0(0)$ & $0(0)$ \\
\hline Preparatory & $15(16.48)$ & $63(38.18)$ & $38(35.18)$ & $17(44.73)$ \\
\hline Strong hints & $4(4.39)$ & $8(4.84)$ & $4(3.70)$ & $3(7.89)$ \\
\hline Mild hints & $0(0)$ & $1(0.60)$ & $1(0.92)$ & $0(0)$ \\
\hline Total & 91 & 165 & 108 & 38 \\
\hline
\end{tabular}

TABLE 11.

CHI- SQUARE VALUE OF COMBINATION C

\begin{tabular}{|l|ll|l|l|}
\hline & Value & df & Sig. \\
\hline Chi-Square & 37.41 & 21 & 0.01 \\
\hline \multicolumn{2}{c}{$p<0.05$} & Critical Value $=32.67$
\end{tabular}

\section{F. Combination D}

In the realization of requests with familiar juniors in combination $\mathrm{D}$, the native speakers employed various direct strategies. They applied indirect strategy as the second preferred type of requesting. Unlike the previous combinations, the native speakers chose various types of direct substrategies, such as Imperative, Want statement, and Hedged performative, attesting to the fact that the speaker's (e.g., professor's) social status is higher than the addressee's (e.g., student's), and therefore, s/he has the right to make a request, and the hearer has the obligation to obey. Accordingly, face-saving strategies are not required, and the choice of strategy tends to move toward directness. Like the native speakers, the higher proficient EFL learners showed productive and varied forms of direct substrategies, whereas the low proficient group still focused on the most direct substrategy-Imperative. This implies that the higher EFL learners show sensitivity to the change of social distance, and in this regard, they have developed sufficient pragmatic competence to display target-like behavior. Accordingly, they realized different forms of direct request, such as Want statement, Hedged performative, and Imperative (see Table 12 for the frequency of strategy types and Table 13 showing the difference):

TABLE 12.

FREQUENCY AND PERCENTAGE OF STRATEGIES BY ALL GROUPS IN COMBINATION D

\begin{tabular}{|l|l|l|l|l|}
\hline Strategy & $\begin{array}{l}\text { Low } \\
\text { F }(\%)\end{array}$ & $\begin{array}{l}\text { Mid } \\
\text { F (\%) }\end{array}$ & $\begin{array}{l}\text { High } \\
\text { F (\%) }\end{array}$ & $\begin{array}{l}\text { Negative } \\
\text { F (\%) }\end{array}$ \\
\hline Mood Derivable & $44(53.01)$ & $62(37.80)$ & $39(36.44)$ & $11(29.72)$ \\
\hline Performative & $0(0)$ & $0(0)$ & $0(0)$ & $0(0)$ \\
\hline Hedge & $3(3.61)$ & $4(2.43)$ & $5(4.67)$ & $3(8.10)$ \\
\hline Obligation & $1(1.20)$ & $4(2.43)$ & $0(0)$ & $2(5.40)$ \\
\hline Want Statement & $1(1.20)$ & $17(10.36)$ & $12(11.21)$ & $5(13.51)$ \\
\hline Suggestory & $1(1.20)$ & $0(0)$ & $0(0)$ & $0(0)$ \\
\hline Preparatory & $31(37.37)$ & $62(37.80)$ & $41(38.31)$ & $15(40.54)$ \\
\hline Strong hints & $2(2.40)$ & $14(8.53)$ & $9(8.41)$ & $1(2.70)$ \\
\hline Mild hints & $0(0)$ & $1(0.60)$ & $1(0.93)$ & $0(0)$ \\
\hline Total & 83 & 164 & 107 & 37 \\
\hline
\end{tabular}

TABLE 13.

CHI- SQUARE VALUE OF COMBINATION D

\begin{tabular}{|c|c|c|c|}
\hline & Value & df & Sig. \\
\hline Chi-Square & 44.39 & 24 & 0.007 \\
\hline
\end{tabular}

\section{G. Combination E}

In this particular combination, the native speakers were prone to use Preparatory as the most appropriate way to realize requests in the situations in which the addressee had a higher power rank, and there was little familiarity between the interlocutors. The next preferred formula of head acts for the native speakers was Strong hints. In other words, they almost exclusively relied on indirectness.

According to the notion of dominance and obligation mentioned earlier, the speaker (e.g., student) has little right to ask the hearer (e.g., professor), and also the hearer has no obligation to comply with the request. On the other hand, since the interlocutors' social distance is greater, the greater use of indirectness is expected. 
The EFL learners did not display the native-like performance. They tended to choose various direct substrategies as the second preferred type of requesting. Thus, they were much more direct than the native counterparts. This might be the reflection of a lack of well-developed pragmatic competence in addressing someone in a higher status. In other words, in spite of having a good command of grammatical competence, the EFL learners showed little evidence of situational variation (see Table 14 for the frequency of strategy types and Table 15 showing the difference).

As most Iranian L2 learners overgeneralize the use of direct requests, it appears that Iranian L2 learners rely on their L1 sociopragmatic knowledge while speaking to unfamiliar superiors. In Eslamirasekh's (1993) study, Persian speakers used significantly more direct strategies in all situations compared to English speakers. That is, the two cultures disagree on the specific directness level appropriate for a given situation (p. 96).

However, the use of indirectness by the speakers of one language does not imply that they are more polite than the speakers of another language. According to Brown and Levinson's (1987) notion of positive politeness, "although the FTAs are performed with redressive action when adopting positive politeness, indirectness is not included among these strategies" (p. 130). So, Eslamirasekh (1993) concludes that the overuse of direct strategies does not imply that Persian speakers are less polite than English speakers because they use direct strategies by the use of mitigating elements (e.g., excuse me, dear friend, etc.) (p. 97).

TABLE 14.

FREQUENCY AND PERCENTAGE OF STRATEGIES BY ALL GROUPS IN COMBINATION E

\begin{tabular}{|l|l|l|l|l|}
\hline Strategy & $\begin{array}{l}\text { Low } \\
\text { F (\%) }\end{array}$ & $\begin{array}{l}\text { Mid } \\
\text { F (\%) }\end{array}$ & $\begin{array}{l}\text { High } \\
\text { F (\%) }\end{array}$ & $\begin{array}{l}\text { Negative } \\
\text { F (\%) }\end{array}$ \\
\hline Mood Derivable & $10(12.82)$ & $25(17.12)$ & $3(3.26)$ & $3(9.00)$ \\
\hline Performative & $0(0)$ & $2(1.36)$ & $4(4.34)$ & $0(0)$ \\
\hline Hedge & $4(5.12)$ & $10(6.84)$ & $13(14.13)$ & $0(0)$ \\
\hline Obligation & $0(0)$ & $2(1.36)$ & $0(0)$ & $0(0)$ \\
\hline Want Statement & $5(6.41)$ & $4(2.73)$ & $8(8.69)$ & $1(3.03)$ \\
\hline Suggestory & $0(0)$ & $0(0)$ & $0(0)$ & $0(0)$ \\
\hline Preparatory & $57(73.07)$ & $97(66.43)$ & $62(67.39)$ & $24(72.72)$ \\
\hline Strong hints & $2(2.56)$ & $6(4.10)$ & $1(1.08)$ & $5(15.15)$ \\
\hline Mild hints & $0(0)$ & $0(0)$ & $1(1.08)$ & $0(0)$ \\
\hline Total & 78 & 146 & 92 & 33 \\
\hline
\end{tabular}

TABLE 15.

CHI- SQUARE VALUE OF COMBINATION E

\begin{tabular}{|l|l|l|l|}
\hline & Value & df & Sig. \\
\hline Chi-Square & 48.56 & 24 & 0.002 \\
\hline \multicolumn{4}{c}{$p<0.05 \quad$ Critical Value $=36.41$}
\end{tabular}

\section{H. Combination $F$}

The native speakers placed more variance in the choice of request strategies when the requests were made toward the addressees who were familiar superiors. They used both direct and conventionally indirect strategies as the preferred types of requesting. That is, by change of social distance between interlocutors, native speakers change their level of directness.

Although the speaker (e.g., customer) has lower social dominance than the hearer (e.g., manager) and, therefore, there is motivation toward indirectness, the interlocutors know each other, and there is a strong trend of using direct type of requesting. The EFL learners, however, did not utilize their requests in native-like ways. They showed a decline in the proportion of Imperative and a shift to conventional indirectness. Since L2 learners are not sensitive enough to the effect of social distance, they do not display significant change in their choice of request strategies in addressing unfamiliar or familiar superiors. In other words, an anticipated trend toward greater directness does not take place with an increase in familiarity by L2 learners, especially with higher proficiency.

The EFL learners did not notice social distance, so they produced more indirect strategies in English, traditionally described to them as being more polite in its request form. That is, it seems that EFL learners overgeneralize stereotypes of an L2 culture by focusing on conventionally indirect strategies. The fact that the low proficient EFL learners in these situations have used more direct requests may not be considered as emanating from their well-developed pragmatic knowledge, but the influence of their L1 competence since the pragmatic trend of overusing directness by the low group has been observed in almost all situations (see Table 16 for the frequency of strategy types and Table17 showing the difference): 
TABLE 16.

FREQUENCY AND PERCENTAGE OF STRATEGIES BY ALL GROUPS IN COMBINATION F

\begin{tabular}{|l|l|l|l|l|}
\hline Strategy & $\begin{array}{l}\text { Low } \\
\text { F (\%) }\end{array}$ & $\begin{array}{l}\text { Mid } \\
\text { F (\%) }\end{array}$ & $\begin{array}{l}\text { High } \\
\text { F (\%) }\end{array}$ & $\begin{array}{l}\text { Negative } \\
\text { F (\%) }\end{array}$ \\
\hline Mood Derivable & $18(21.42)$ & $16(9.75)$ & $4(3.80)$ & $4(10.64)$ \\
\hline Performative & $0(0)$ & $3(1.82)$ & $3(2.85)$ & $0(0)$ \\
\hline Hedge & $3(3.57)$ & $13(7.92)$ & $4(3.80)$ & $2(5.12)$ \\
\hline Obligation & $0(0)$ & $1(0.60)$ & $0(0)$ & $2(5.12)$ \\
\hline Want Statement & $5(5.95)$ & $19(11.58)$ & $10(9.52)$ & $8(20.51)$ \\
\hline Suggestory & $0(0)$ & $0(0)$ & $0(0)$ & $0(0)$ \\
\hline Preparatory & $57(67.85)$ & $112(68.29)$ & $84(80.00)$ & $20(51.28)$ \\
\hline Strong hints & $1(1.19)$ & $0(0)$ & $0(0)$ & $3(7.69)$ \\
\hline Mild hints & $0(0)$ & $0(0)$ & $0(0)$ & $0(0)$ \\
\hline Total & 84 & 164 & 105 & 39 \\
\hline
\end{tabular}

TABLE 17.

CHI- SQUARE VALUE OF COMBINATION F

\begin{tabular}{|l|l|l|l|}
\hline & Value & df & Sig. \\
\hline Chi-Square & 74.77 & 24 & 0.002 \\
\hline \multicolumn{4}{|c|}{$p<0.05 \quad$ Critical Value $=32.67$}
\end{tabular}

As an ILP research to investigate the sociopragmatic features of Iranian EFL learners, this experiment contributes to the field of interlanguage pragmatics. By enhancing our understandings of the interlanguage features of EFL learners in English speech act of request, it is hoped that this study will illustrate the significance of interlanguage pragmatic studies among EFL educators and researchers and stimulate their research interest in this fast growing discipline.

This type of study not only is useful in supplying L2 teachers and materials developers with native speakers' baseline data, but also indicates how and in what situations certain groups deviate from native speaker norms. It should, therefore, be a major goal to teach relevant general cultural schemata and to make nonnative learners aware of differences between their own cultural schemata and those of native speakers.

In line with the results of other studies (Alcon, 2005; Bardovi-Harlig \& Taylor, 2003; Kasper \& Rose, 1999), one of the major findings of the present research is that if $\mathrm{L} 2$ teachers in foreign language classrooms provide L2 learners with relevant input, they can develop appropriate request behaviors similar to those of native speakers. However, the present study merely investigated the directness level of speech act of request and did not look at the length of the requests produced, the use of politeness markers, or external and internal modifications of the request. Therefore, further studies are needed to unveil and explore these issues.

\section{CONCLUSION}

This study was designed to address the important issue of pragmatic development of request strategies in Iranian EFL learners in order to determine whether and to what extent interlanguage realization of the speech act of requesting by Iranian learners differs from request realization by native speakers in English.

The conventionally indirect strategy might be a universal method of making request toward the addressees (Ellis, 1994; Trosborg, 1995). The present study suggests a positive correlation between the use of indirect type of requesting and the EFL learners' proficiency level, that is, Iranian EFL learners display developmental patterns of request strategies.

It was observed that the high proficient EFL learners overused the conventional indirect strategy type. So, in line with the findings of other interlanguage studies (Byon, 2004; Rue, et al., 2007), in the present experiment, the higher EFL learners appeared to develop a greater sensitivity to the use of more polite strategies in requesting than what was seen in the native speakers. This study also supports Ellis's (1994) view that even advanced L2 learners do not acquire fully native-like ways of requesting.

In terms of the influence of the social variables, the findings of this research reveal that, as far as social dominance is concerned, the EFL learners displayed closer performance to the native speakers. But in terms of social distance, many differences were observed between the types of request strategy made by the native speakers and Iranian EFL learners. It seems that the EFL learners had not acquired sufficient sociopragmatic knowledge to be able to display the proper social behavior. That is, they were not sensitive to both social power and social distance.

L2 learners may have access to the same range of speech acts and realizations as do native speakers, but they differ from native speakers in the strategies they choose. More importantly, L2 learners must be aware of an L2 sociocultural constraint on speech acts in order to be pragmatically competent. Following Rose and Kasper (2001), the claim advanced here is that although highly context-sensitive in selecting pragmatic strategies in their own language, L2 learners may underdifferentiate such context variables as social distance and social power in an L2.

It is important to note that, as predicted by politeness theory (Brown \& Levinson, 1987), power relationship, social and psychological distance, and degree of imposition constrain communicative action universally, but L2 learners' assessment of the weight and values of these universal context factors varies substantively from context to context as well as across speech communities. There is, thus, a strong indication that instructional intervention may be facilitative to, or even necessary for, the acquisition of L2 pragmatic ability. 
Finally, it is hoped that research in L2 pragmatics will not only improve our understanding of pragmatic development in speech act realization and of the nature of strategies, but will also enable SLA researchers to incorporate effective methods of teaching pragmatics in EFL classrooms.

\section{APPENDIX A DISCOURSE COMPETITION TEST (DCT)}

NAME:

MAJOR:

NATIONALITY:

Directions: Please read the following descriptions of situations and write what you would say in each situation.

1 - You are trying to study in your room and hear loud music coming from another student's room down the hall. You don't know the student, but you decide to ask him/her to turn the music down. What would you say?

2- You are at a record store with your best friend. There's a CD you really want to buy, but you don't have any money. How do you ask your friend to lend you money?

3- You are studying at home. Your younger brother opens the window and the cold wind blows right into your face and bothers you. You want to ask him to close it. What would you say?

4- You have bought a shirt from a big store for your father, but he doesn't like its color. You decide to go to the clothes store and ask the manager of the store to allow you to exchange the shirt. What would you say?

5- Your friend and you go to a restaurant to eat. You want to order and need to ask the waiter for the menu. What would you say?

6- You are writing your thesis and need to interview the president of a university whom you don't know. You know the president is very busy, but still want to ask her/him to spare one or two hours for your interview. What would you say?

7- For registration you need to fill out a couple of forms. You search all of your pockets and can not find a pen. You want to ask another student who is sitting next to you in the department hall. What would you say?

8- You were absent last Friday history class that you are enrolled in. So, you decide to borrow your friend's notes to catch up with the rest of the class. What would you say to get this friend to lend you the notes?

9- You are a professor teaching a course in psychology. You want one of the students who is very competent and always contributes class discussion, to present a paper in a class a week earlier than scheduled. However, midterm exams are next week and she has a heavy course load. What would you say?

10- You really have to take this course in order to graduate, but you found that the course is already closed. So, you decide to ask the professor, whom you don't know, to allow you to take this course. What would you say to get this professor to permit you to participate in this course?

11- You have a paper due in one of your classes next week. However, you will be very busy this week and don't have any time to write it. You go to your professor's office to ask for more time to write the paper. How do you request an extension?

12- You are a librarian. Today, a student is making a noise and disturbing other students. You don't know that student. However, you decide to ask the student to quiet down. What would you say?

13- A friend of yours from out of the town is paying you a visit. Both of you would like to take a photo together to remember this happy moment. You decide to ask a nearby person who is stranger to you, to do this favor. What would you say?

14- You and your friend are members of the college skiing club. You have just arrived at the mountain and see that your friend is applying sunscreen lotion. You want to use that lotion because you have forgotten to bring your own. How would you ask your friend?

15- Your English midterm exam is approaching, and you find that the date of the test is the same as that of your brother's wedding. You decide to ask the professor whom you don't know personally to rearrange another day especially for you to take this test. What would you say?

16- Your mother will be visiting from out of town and you want to pick her up at the airport. However, her flight arrives at 3:00 PM, but you have to work until 5:00 p.m. How do you ask your boss to let you out of work early?

17- You are a teacher. It's the beginning of the semester and you don't know the students yet. In class, the mobile phone of one of your students rings. You want to ask her/him to turn off the mobile phone. What would you say?

18- You are going to visit your friend, who lives in the college dormitory. You are on the campus, but you don't know where the room is? You are going to ask a student for the location of the dorm. How would you ask the student?

19- It's 7:00 a.m. and you want to go to work. You have to leave your daughter alone because her baby sitter is late. You decide to ask your friend, who lives in your neighborhood to take care of your little daughter in the meanwhile. What would you say?

20- You are the manager of a company. You are in a meeting with the other members of your company. You need to write some notes, but you realize that you don't have any paper. You turn to the person sitting next to you and you know her/him very well. What would you say?

21- Your class has just finished and you need a ride home. Your fellow classmate who was supposed to give you a ride is absent. As you come out of the class, you see an assistant professor. You decide to ask him/her to give a lift to you. What would you say? 
22- You are the president of a university. Something is wrong with your computer. You have to finish some work which is due tomorrow. One of the students is very skillful in fixing computers. You don't know him/her. However, you want to ask him/her to fix your computer. What would you say?

23- You are applying for a scholarship, and you decide to ask a professor, who knows you very well as your academic advisor, to write a recommendation letter for you. What would you say to ask her/him to do this favor for you?

24- You are the owner of a big bookstore. It is the beginning of the semester, and you are very busy. Today you want to extend business hours by an hour. So, you decide to ask your clerk whom you know quite well, to stay after store hours. What would you say?

\section{REFERENCES}

[1] Alcon, S. E. (2005). Does instruction work for learning pragmatics in the EFL context? System 33.3, 417-435.

[2] Austin, J. (1962). How to do things with words. In A. Jaworski \& N. Coupland (eds.), The discourse reader. New York: Routledge, 63-75.

[3] Bardovi-Harlig, K. \& Z. Dörnyei. (1998). Do learners recognize pragmatic violations? Pragmatic versus grammatical awareness in instructed L2 learning. TESOL Quarterly 32.2, 42-71.

[4] Bardovi-Harlig, K. \& M. R. Taylor (2003). Teaching pragmatics. http://exchanges.state.gov/education/engteaching/(accessed 22/11/2007).

[5] Brown, P. \& S. C. Levinson. (1987). Politeness: Some universals in language usage. Cambridge: Cambridge University Press.

[6] Bouton, L. F. (1994). Conversational implicature in a second language: Learned slowly when not deliberately taught. Journal of Pragmatics 22, 157-167

[7] Byon, A. S. (2004). Sociopragmatic analysis of Korean requests: Pedagogical setting. Journal of Pragmatics 36, $1973-1704$.

[8] Chen, S. (2007). Interlanguage requests: A cross-cultural study of English and Chinese. The Linguistics Journal 2.2, 32-52.

[9] Ellis, R. (1994). The studies of second language acquisition. Oxford: Oxford University Press.

[10] Eslamirasekh, Z. (1993). A cross-cultural comparison of requestive speech act realization patterns in Persian and American English. Pragmatic and Language Learning 4, 85-103.

[11] Fowler, W. S. \& N. Coe (1976). Nelson English language texts. London: Thomas Nelson and Sons, Ltd.

[12] Francis, C. (1997). Talk to me! The development of request strategies in nonnative speakers of English. Working Papers in Educational Linguistics 13.2, 23-40.

[13] Garcia, P. (2004). Developmental differences in speech act recognition: A pragmatic awareness study. Language Awareness $13.2,96-115$.

[14] Harlow, L. L. (1990). Do they mean what they say? Sociopragmatic competence and second language learners. The Modern Language Journal 74, 328-349.

[15] Hassall, T. (2003). Requests by Australian learners of Indonesian. Journal of Pragmatics 35, 1903-1928.

[16] Iimuro, A. (2006). Conversation analysis of e-mail requests by second language speakers. Second Language Studies 24.2, 65113.

[17] Kahraman, B. \& D. Akkus. (2007). The use of request expressions by Turkish learners of Japanese. Journal of Theory and Practice in Education 3.1, 122-138.

[18] Kaneko, T. (2004). Request production by Japanese EFL learners: An SST Corpus-Based study. http://nels.nii.ac.jp/els/110004688559.pdf;jsessionid=DD1E8C2984AA71 (accessed 20/11/2007).

[19] Kasper, G. (1992). Pragmatic transfer. Second Language Research 8, $203-231$.

[20] Kasper, G. (1984). Pragmatic comprehension in learner-native speaker discourse. Language Learning 34, 1-20.

[21] Kasper, G. \& R. Schmidt (1996). Developmental issues in interlanguage pragmatics. Studies in Second Language Acquisition $18,149-169$.

[22] Kasper, G. \& K. R. Rose (1999). Pragmatics and SLA. Annual Review of Applied Linguistics 19, 81-104.

[23] Kim, J. (1995). "Could you calm down more?" Requests and Korean ESL learners. Working Papers in Educational Linguistics $11.2,67-82$.

[24] Koike, D. A. (1989). Pragmatic competence and adult L2 acquisition: Speech acts in interlanguage. The Modern Language Journal 73, 279-289.

[25] Kubota, M. (1996). Acquaintance or Fiancée: Pragmatic differences in requests between Japanese and American. Working Papers in Educational Linguistics 12.1, 23-38.

[26] Leech, G. (1983). Principles of pragmatics. London: Longman.

[27] Levinson, S. C. (1983). Pragmatics. Cambridge: Cambridge University Press.

[28] Lwanga-Lumu, J. C. (2002). Internal request modification by first and second language speakers. Journal of Language Teaching 36.3\&4, 289-304.

[29] Marti, L. (2006). Indirectness and politeness in Turkish-German bilingual and Turkish monolingual requests. Journal of Pragmatics 38, 1836-1869.

[30] Olshtain, E. \& A. D. Cohen (1991). Teaching speech behavior to nonnative speakers. In M. Celce-Murcia (ed.), Teaching English as a second or foreign language. Boston: Heinle and Heinle Publishers, 154-169.

[31] Parent, M. P. (2002). The production of requests by Catalan learners of English: Situational and proficiency level effects. ATLANTIS 2, 147-168.

[32] Rinnert, C. \& H. Kobayashi (1999). Requestive hints in Japanese and English. Journal of Pragmatics 31, $1173-1201$.

[33] Rose, K. R. (2000). An exploratory cross-sectional study of interlanguage pragmatic development. Studies in Second Language Acquisition 22, 27-67.

[34] Rose, K. R. \& G. Kasper (2001). Pragmatic in language teaching. Cambridge: Cambridge University Press. 
[35] Rue, Y. J., G. Zhang \& K. Shin (2007). Request strategies in Korean. http://espace.lis.curtin.edut.au/archive/00002319/01/pdf (accessed 10/11/2007).

[36] Ruzickova, E. (2007). Strong and mild requestive hints and positive-face redress in Cuban Spanish. Journal of Pragmatics 39 , 1170-1202.

[37] Searle, J. (1969). Speech acts: An assay in the philosophy of language. Cambridge: Cambridge University Press.

[38] Takahashi, S. (1996). Pragmatic transferability. Studies in Second Language Acquisition 18, 169-223.

[39] Takahashi, T. \& L. M. Beebe (1993). Cross-linguistic influence in the speech act of correction. In G. Kasper \& S. Blum-Kulka (eds.), Interlanguage pragmatics. New York: Oxford University Press, 110-125.

[40] Trosborg, A. (1995). Interlanguage pragmatics: Requests, complaints, and apologies. Berlin: Mouton de Gruyter.

[41] Weizman, E. (1993). Interlanguage requestive hints. In G. Kasper \& S. Blum-Kulka (eds.), Interlanguage pragmatics. New York: Oxford University Press, 123-137.

[42] Wouk, F. (2006). The language of apologizing in Lombok, Indonesia. Journal of Pragmatics 38, 1456-1486.

Alireza Jalilifar is an Assistant Professor of Applied Linguistics at Shahid Chamran University of Ahvaz, Iran. He has published in several international and national journals, including Journal of College Reading and Learning, Greek Journal of Applied Linguistics, System, RELC, and Journal of Language and Translation and has presented papers in conferences such as Systemic Linguistics and IPRA. His recent book Research Article in Applied Linguistics: A Genre-Based Writing Guide provides an accessible introduction to research article writing. His main interests are second language writing, genre analysis, and academic discourse.

Mahmood Hashemian is an Assistant Professor of Applied Linguistics at Shahrekord University. His area of research includes cognitive-semantic linguistics, sociolinguistics, and applied linguistics. He has published articles in academic journals and given lectures in conferences such as TELLSI (4, 7, \& 8), LDP2010, and the ELT Conference in the Islamic World.

Madine Tabatabaee is an M.A. TEFL graduate of Islamic Azad University, Ahvaz Center for Science and Research Branch. She is currently teaching English at Ahvaz language schools at various levels. Her areas of interest include pragmatics, sociolinguistics, and discourse analysis. 